This is an author produced version of a paper published in Managing Leisure.

This paper has been peer-reviewed but may not include the final publisher proof-corrections or pagination.

Citation for the published paper:

Jansson, M., Ramberg, U.. (2012) Implementation and effects of user participation inplayground management: a comparative study of two Swedish municipalities. Managing Leisure. Volume: 17, Number: 1, pp 1-13. http://dx.doi.org/10.1080/13606719.2011.638204.

Access to the published version may require journal subscription. Published with permission from: Taylor \& Francis.

Standard set statement from the publisher:

This is an Accepted Manuscript of an article published by Taylor \& Francis Group in Managing Leisure on 24/04/2012, available online:

http://www.tandfonline.com/doi/abs/10.1080/13606719.2011.638204\#.VcMV6fnt/Bc.

Epsilon Open Archive http://epsilon.slu.se 


\title{
Implementation and effects of user participation in playground management: a comparative study of two Swedish municipalities
}

Cite as: Jansson, M., Ramberg, U. (2012). Implementation and effects of user participation in playground management: a comparative study of two Swedish municipalities. Managing Leisure 17(1), 1-13.

DOI:10.1080/13606719.2011.638204

First author: Märit Jansson, PhD, Landscape Architect

Swedish University of Agricultural Sciences,

Department of Landscape Management, Design and Construction

P.O. Box 66, SE-230 53 Alnarp, Sweden

Marit.Jansson@ltj.slu.se

Second author: Ulf Ramberg, $\mathrm{PhD}$, Assistant professor

Lund University,

School of Economics and Management

P.O. Box 7080, SE-220 07 Lund, Sweden

Ulf.Ramberg@fek.lu.se

\begin{abstract}
This paper describes and analyses how customer orientation strategies, with the focus on user participation, are implemented in playground management and their effects on managers’ attitudes and work with physical playgrounds. A comparative case study was conducted in two Swedish municipalities that involve users in different ways: through a manager-driven participation process and through informal user-initiated dialogue. The empirical material
\end{abstract}


consisted of qualitative interviews with professionals in the management organisations and studies of local playgrounds. Implementation of strategies for user participation and tactical management activities appeared to be of importance. The manager-driven participation strategy was associated with a particularly positive attitude among managers, but also difficulties such as maintaining continuous dialogue with users. The small differences found in playground provision between the two municipalities give reason to question the physical effects of participation processes, and show the need for further research.

Keywords: strategy implementation; customer orientation, playgrounds; public sector management; user participation

\section{Introduction}

The New Public Management (NPM) movement has had a major impact on the management of local governments in the past two decades. NPM consists of a cluster of ideas borrowed from the private sector on how to manage organisations (Power, 1997). One of the most common ideas is to view citizens and other users of local government services as customers (Maddock, 2002; Walker and Boyne, 2006; Wichowsky and Moynihan, 2008). One effect of this change is decentralisation of responsibility in the local government. Politicians get more explicit responsibility for service provision and officials for designing the work needed to realise this provision (Bergström et al., 2008). Another effect is increased interest in the quality and results of the services and products offered (Kuhlman et al., 2008). Customer orientation also has an impact on how employees in the local government organisations perceive their own knowledge and perception of quality and results relative to the customers' opinions. 
Organisational flexibility and customer orientation involve working in consistent processes, freeing abilities and creativity and motivating staff to work towards shared goals (Rodrigues and Halvorson, 1996) with a holistic view including communication within and between different groups and levels inside and outside the organisation (Grint, 1994; Fernandez and Rainey, 2006).

One public service commonly provided by municipal organisations or similar is outdoor playground provision. Free play in the public open space is reported to support children's development and also the creation of a democratic society if prioritised by local governments, managers and decision-makers (Hart, 2002). Problems in adapting to specific user needs may be related to features of the management organisation such as poor internal relations, inadequate knowledge, tight budgets and negative personal attitudes (Prellwitz and Tamm, 1999). However, little is known about strategic approaches involving user focus within playground management and their effects. How do the managers work when executing the politicians' wishes to be more user-orientated? How are opinions concerning playground provision handled by managers? How does the level of user participation affect playground managers and their work?

In this paper, two Swedish municipal organisations are studied and compared. The aim is to describe and analyse how customer orientation strategies, with the focus on user participation, are implemented in management work and the effects they have on managers' attitudes and work with physical playgrounds. 


\section{Municipal strategies for playground provision}

Swedish playground provision, which was long affected by expert perspectives, top-down control and functional separation, is increasingly becoming a strategic question for municipal organisations (Jansson and Persson, 2010). National directions on the location and size of play areas have traditionally affected playground provision in many countries, e.g. Sweden (Bucht, 1997), Denmark (Eriksen, 1985), the UK (Frost, 1986) and the US (Frye, 1964; Hart, 2002), but standard-based thinking in planning and governance is being replaced by new approaches (Albrechts et al., 2003). Strategic documents for playground provision in more local contexts are being developed by a number of cities and municipalities. The development of a play policy and playground priority plan in Dunedin, New Zealand, in 1994 was described as a “structured way of solving a long-time problem of formal public play opportunities” (Quigg, 1999, p. 60). Woolley (2007) claims that local authority open space strategies can allow adaptation to local needs and preferences for play spaces while Taylor et al. (2008) see local authorities' strategic approaches to play facility management as important. Without any regulations there is a risk of children's environments losing priority (Björklid and Nordström, 2007). In Sweden, the lack of planning standards in recent years combined with high demands on equipment safety and low budgets have commonly led to fewer units and great disparity in playground numbers and density between municipalities (Jansson, 2008). Today, public playgrounds in Sweden are also commonly unstaffed. The development and implementation of strategies on a local level may be a way of ensuring the provision of play spaces and adapting these to user needs.

\section{Strategies and their implementation in local governments}

The term strategy is under continuous re-definition (Ghemawat, 2006). For example, the traditional, rational, top-down view of strategy has been challenged by a more process- 
directed approach where the formation of strategy is integrated with its implementation (Quinn, 1982; Mintzberg et al., 1998) and is affected by changing conditions (Rumelt et al., 1994; Mattisson, 2000). Within the public sector, the context described in this paper, strategy can be defined as “a pattern of purposes, policies, programs, actions, decisions, and/or resource allocations that defines what an organisation is, what it does, and why it does it” (Bryson, 1995, p. 130). Adding the dimension of the context in which the organisation finds itself (Mintzberg et al., 1998), strategy is also “a comprehensive order for an organisation’s activities in relation to its surroundings” (Mattisson, 2000, p. 20). Knutsson et al. (2008) propose a process-directed approach concerning strategies in Swedish local governments. They also pinpoint the importance of municipalities’ relations to their surrounding environment and to past decisions and claim that the way in which managers implement the strategies and goals set by politicians has a strong impact on their performance.

For strategic thinking in municipal open space management, Randrup and Persson (2009) propose a model comprising three levels of activity: policy (political), tactical (professional) and operational. According to them, strategies should be set on the policy level, but based on analyses and plans produced on the tactical level. A major focus on operational level activities (e.g. upkeep and maintenance) carries a risk that the organisation will lack sufficient overview, long-term vision and strategies (Randrup and Persson, 2009). Guest and Taylor (1999) identified senior managers (tactical level) as key actors, more influential than politicians in setting aims and objectives for leisure provision because they consult line level managers (operational) and make recommendations to politicians (policy). Tactical and operational activities are preferably based on cooperation with both internal and external stakeholders (Randrup and Persson, 2009). Mattisson (2000) emphasises that politicians are not an external factor and that strategic approaches can have both politicians and professionals 
as initiators. The three organisational levels can be inserted into a playground management model (Fig. 1), developed from existing models (Randrup and Persson, 2009), that includes provision of playgrounds, users and user benefits. Using this model, playground management can be defined in a comprehensive way, comprising a number of activities, actors and interrelations.

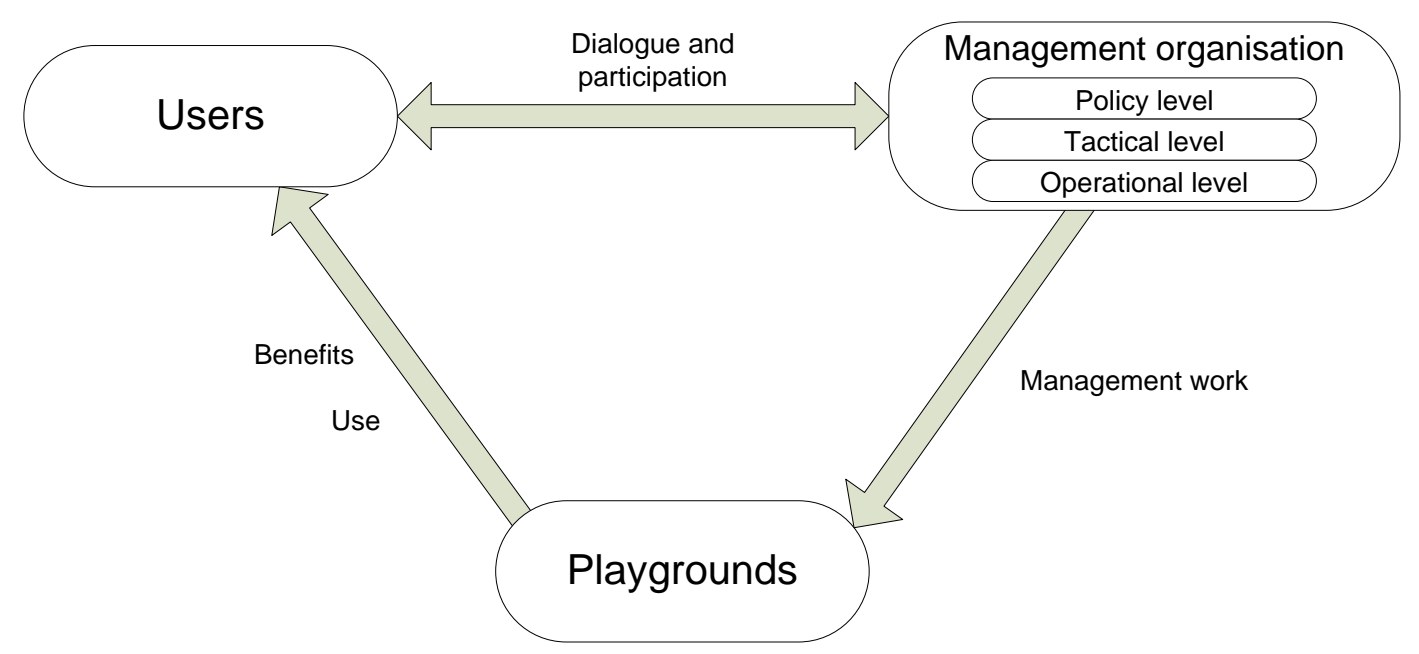

Fig. 1. Playground management model, developed from Randrup and Persson (2009).

Internal and external communication are both claimed to be important in public sector strategic management and performance (Tourish and Tourish, 1996; Pandey and Garnett, 2006; Fernandez and Rainey, 2006). Involving users or other stakeholders through dialogue and participation forms part of public sector strategy formation (Bryson, 1995; Poister and Streib, 1999; Albrechts et al, 2003; Fernandez and Rainey, 2006), and can result in learning both for users and for management professionals, provided that they play an active role in the process (Joyce, 2000). Bottom-up consultation and participation can be combined with strategic thinking even in small local authorities (Dereli, 2003). Goodlad et al. (2005, p. 926) consider participation 'both means and ends' and identify a particular need for more empirical studies of participation impact, rather than of process only. 


\section{User participation in playground management}

Children and other users have traditionally had little influence on public playground provision (Hart, 2002). However, participation by children has been proposed as a way of improving environments for children (Hart, 1992; Francis and Lorenzo, 2002; Freeman and Aitken-Rose, 2005). Dialogue and collaboration between children and adults are regarded as particularly fruitful (Iltus and Hart, 1995). Children’s suggestions are often valuable to all users (Tonucci and Rissotto, 2001). However, children may have problems in making themselves heard and may become involved at too late a stage in the process or in ways that do not reflect their perspectives (Kylin, 2004). Furthermore, the results of children's participation can depend heavily on the approach and methods used (Francis and Lorenzo, 2002; Cele, 2006).

A possible difficulty can be that participation processes mainly attract certain categories of people (Beierle and Konisky, 2001) and certain ‘types’ of young people might be included more than others (Nairn et al., 2006). In examples described by Beierle and Konisky (2001), stakeholder involvement in planning in general successfully influenced decisions reflecting public values and knowledge, improved relationships between the actors involved and increased knowledge among stakeholders and managers, but was less successful in practical implementation. Goodlad et al. (2005) found both positive and negative outcomes of community involvement reported in the literature. However, experiences of child participation show positive changes for children, the environment and the entire local society (Hart, 1992). 


\section{Evaluating strategy implementation and its effects}

To evaluate the implementation of strategies within playground management, two municipal organisations with different types of user participation were compared. Playground management to implement strategies, particularly concerning approach to users and participation, can be expected to affect all parts of the playground management model. Users' perspectives on the effects are important (Taylor et al., 2008), but were beyond the scope of this paper. The study focused on how managers implement strategies decided upon by politicians.

According to Vedung (2006, p. 409), the effects of public sector policy can be researched through process evaluation using qualitative approaches, with the subjects evaluated in their 'natural surroundings'. A comparative case study (Stake, 1995) was therefore conducted in two Swedish municipalities. The approach adopted involved qualitative interviews with individuals working with playground management and studies of existing playgrounds in the regional centres of the two municipalities.

The playground management organisations in the two municipalities, here called $\mathrm{X}$ and $\mathrm{Y}$, were deliberately selected from among 23 Swedish municipalities (out of 290) included in an earlier telephone survey about local playground management (Jansson, 2008). Since deregulation in the early 1990s concerning how Swedish municipalities organise their work and responsibilities, there has been a huge change in the municipal sector (Bergström et al., 2008). This has resulted in a variety of structures and resources, making it difficult to compare municipalities. One criterion for the case selection in this study was therefore to find two comparable municipalities. The cases selected also had to represent two different strategic approaches to user involvement. 
The two organisations selected for study were deemed interesting, comparable in many aspects, but different in terms of playground management strategy, particularly concerning user focus. In both municipalities, playground management was mainly carried out by units within divisions dealing with parks, classified under technical departments and managing around 100 playgrounds each. Both described a financially and politically favourable situation, with playground provision in an improvement phase. Both municipalities were situated in southern Sweden, in areas with wide access to nature, and had around 30000 inhabitants, of whom about half lived in the regional centre and half in surrounding villages. Municipality X had involved users in an organised, manager-initiated and large-scale participatory process when revising the playgrounds five years before the present study, while in municipality Y playground provision work was based more on political decisions, although preferences expressed by users were considered. The two cases thus provided an opportunity to compare two different ways to implement chosen strategies and the effects of these as perceived by the professionals and in terms of the physical playgrounds.

\section{Interviews with playground managers}

To follow implementation of a user involvement strategy concerning playgrounds, the interviews were limited to individuals working with municipal public playgrounds on the tactical level or on the operational level if they had particular responsibilities for playgrounds, excluding other park workers and politicians. Initial group interviews provided an overall picture of the management organisations and of staff members of interest for individual interviews. In both municipalities, four individuals attended the group interview. Three others of interest to the study were then identified in municipality $\mathrm{X}$, while it emerged that two of those included in the group interview in municipality $\mathrm{Y}$ worked with preschool playgrounds 
only. In Swedish municipalities preschool playgrounds are often the responsibility of school boards which have their own strategies for play provision. Those two persons were therefore not individually interviewed.

In municipality $\mathrm{X}$ the seven interviewees were: two physical planners, one financial officer, one forest manager, one works manager, one foreman and one working foreman with responsibility for maintenance and safety inspections. They were of varying age from late 20s (one physical planner) to early 60s (the foreman) and most of them worked in the parks and streets division of the municipal authority’s technical department.

In municipality $\mathrm{Y}$ only two persons were regarded as being involved in the management of public playgrounds: the head of the parks division, who was also foreman and physical planner, and a park worker with responsibility for playground maintenance and safety inspections. Both were around 60 years old.

The individual interviews were qualitative and semi-structured (Kvale, 1996) and focused on five themes about playground management work and its conditions, namely: strategies, knowledge, decision-making, users and personal attitudes. The themes aimed to bring the conversation from a general level about the interviewee's work to more a personal level about opinions and attitudes. Each interview lasted on average 75 minutes and most were recorded. One was documented by note-taking, as one person in municipality Y refused to be recorded. Two of the recorded interviews were partly documented by complementary note-taking because they were conducted outdoors in sometimes windy playgrounds (with the working foreman in municipality $\mathrm{X}$ and the head of the parks division in municipality $\mathrm{Y}$ ). 


\section{Playground studies}

The municipal playgrounds sited in the regional centres of municipality $\mathrm{X}$ and $\mathrm{Y}$ were visited on one occasion and documented with photographs and written descriptions of size, content, character and location. It was necessary to get an overall picture of the local playgrounds because they were considered effects of past and present planning and management strategies.

\section{Analysis}

The information provided by each interviewee was analysed qualitatively through condensation into narratives (Bryman, 2008), giving an overall description of the work and strategies within the management organisations. The playground observations resulted in a qualitative description of the provision in each regional centre, which was compared with the findings from the organisations. The two cases were then analysed and compared with each other in terms of strategy implementation of user involvement in the work and as affecting managers’ attitudes and the municipalities’ playground provision.

\section{Strategies and effects in municipality $X$ and $Y$}

\section{Municipality X: High level of cooperation, with user participation process}

The interviewees in municipality $\mathrm{X}$ described playground management as being mainly based on a user participation process performed five years before the present study. It had been proposed by a financial officer employed in the technical department, who after attending a training course in user involvement methods wanted to test these in playground development. Since the playgrounds were already considered in need of improvement in order to meet requirements on safety and disabled access, extensive refurbishment based upon user 
participation had been agreed as an important strategy at the political level. First, a questionnaire survey had investigated attitudes towards local playgrounds, qualities that users looked for in terms of closeness, content, etc. Thereafter, focus groups with different categories of users, children and adults, with variation in e.g. age and place of residence represented, discussed the results of the survey and how playground provision might be improved. Demographic studies of the distribution of children living in the municipality resulted in a preliminary list of priorities for playground units and distribution of funding between residential areas. In each area, interested users, mainly parents and children, gathered at meetings where they were given an insight into the budget, equipment costs, equipment safety standards and possibilities for them to make contributions to the construction work. Together with tactical and operational level managers, users made decisions on which units to prioritise and developed design solutions. Some, mainly parents, also got involved in the construction work, but it proved more difficult to involve users in operational activities than in strategic and tactical aspects.

The playground management organisation thereafter mainly concentrated on implementing proposals developed at the consultation meetings, a task that was almost finished at the time of the present study, and trying to keep in contact with users, mainly through contact individuals. The playground management organisation in municipality $\mathrm{X}$ also wanted to implement new ideas, such as installing play sculptures in the city centre. In the process, the politicians had approved the proposals but played a rather peripheral role, while much power had been given to those users who participated. The tactical management level appeared to have a high level of cooperation, since many professionals of different categories and units had been involved in the playground management work, including physical planners and a forest manager. 


\section{Effects of user participation in municipality $X$}

The interviewees described effects of the process on all three parts of the playground management model: users, managers and playgrounds. In terms of the actual municipal playgrounds, the refurbishment based on user participation appeared to have resulted in some diversification. Some larger units had been developed, often with features other than traditional play equipment, for example areas for ball games, barbecue facilities and cycle trails. One very large playground had been installed close to nature. As part of a former strategy, there were also two centrally located playgrounds. Some smaller play units had been kept with little or no change. However, a few of the prioritised playgrounds appeared to have adopted an almost private character and might even be difficult for everyone to find.

In terms of managers and users, the participation process appeared to have affected the management work, the attitudes to work and the attitudes to users. The interviewees described indications of users being pleased with the new provision, which had solved some earlier problems, and reported that the participation process had resulted in mutual learning for managers and users and made it possible to get support for plans to slightly diminish the number of playgrounds, which over time meant lower management and maintenance costs. The participatory process had resulted in more knowledge about playgrounds and their use for the professionals within the management organisation. The former strategy of having centrally located playgrounds was confirmed as being positive for users. Several interviewees had also discovered that user preferences did not always match management plans and expectations and that those preferences could vary greatly depending on neighbourhood. Users had wanted one playground to be very large, but surprised the managers by preferring to have it close to nature, not in an area where many people live. In some areas, users had 
proposed non-traditional solutions such as forest playgrounds, but had commonly wanted surprisingly traditional designs. In cases where users had proposed unconventional ideas, they had often been inspired by playgrounds in neighbouring municipalities. Although users often liked the idea of having fewer but larger units, that was not the case in all residential areas. Several of the managers had learned that they had to ask users for information about their actual needs and preferences to understand them, and that users could also gain more understanding of managers' work. Interviewees claimed that giving the users all pertinent knowledge about the limitations and conditions for playground management, particularly equipment costs and safety standards, had resulted in successful cooperation between users and managers to create as much play provision as possible using the available resources.

The interviewees involved had positive memories and experiences of the user consultation process and commonly also a positive attitude to involving users in management questions. However, two individuals who were not employed in the organisation during the process were less enthusiastic about it than those with personal experiences or those who had worked with playground management during that time. Initiatives taken to designate some parents as contact individuals became more difficult after some years, as users had already changed. Many of the interviewees appeared very pleased with the participation process of the past five years, while others considered that a continuous process was needed. There was also criticism that the digital catalogue of playground provision information had not been completed, something that the physical planners in particular considered important for strategic work. Conforming to safety standards and other implications was considered a main goal for the management, which had appointed the working foreman with knowledge of the standards as a key individual. 


\section{Municipality Y: Traditional with informal user consultation}

In municipality $\mathrm{Y}$, improving the playground provision was a high priority and new investment was being devoted to it. According to a decision made on the political level, the local strategy for playground provision included enlarging and developing two of the municipal playgrounds into excursion destinations and meeting places and keeping the other existing smaller units. As a result, one playground had already been enlarged and developed to suit mainly young children's play and to be a destination for outings. Current work was mainly being directed towards developing the second priority playground, located close to a senior school, as an investment in older children and a way of giving youngsters a designated site. All existing playgrounds were retained. The number of playgrounds was described as high and the units densely placed in some areas, but a reduction was considered to be difficult due to the high priority of playground provision at the political level and its importance to users. In the group interview, municipality $\mathrm{Y}$ was described as having good cooperation between its different departments and divisions. However, the division for parks and playgrounds formed a small part of the technical department in the municipality and appeared isolated from strategic decisions, as investments in provision were mainly based upon initiatives and decisions from politicians. The interviewees considered this to be the correct order of things, even if they did not always find the strategic decisions suitable for playground improvement. The municipal physical planning department, which was a separate entity from the technical department, did not always show understanding of playground management issues but added playgrounds to their plans in a mechanistic way without consulting the playground managers. The managers described themselves mainly as an operational unit, but as making many operational and tactical decisions on a day-to-day basis, for which they had to request more funding. Both the head of the parks division and the park worker expressed many thoughts about playground management and strategy implementation, even if they did 
not agree on all questions. For example, the head of the parks division referred to the usefulness of investigating the ages of children living close to playgrounds to adapt the play equipment, while the park worker claimed that it was better if all playgrounds suited all age groups, since the users change fast.

Although the political level was responsible for strategy formation concerning user orientation, the managers were also keen on adapting to user needs and preferences in informal ways. Their work was influenced by input that, in different ways, came directly from the users or from their own thoughts, understandings and observations of what children and other users want in the playground settings. They had started leaving shrubbery close to playgrounds, as they had observed that shrubs were used for play since the children had worn out the ground around them. Examples were given of when users had contacted the managers by phone or approached them when working on the playgrounds with requests and feedback, and they were prepared to see if such requests could be fulfilled. They described difficulties in meeting some requests because of limiting factors such as safety standards and lack of space. They also believed that too active user participation could lead to problems, since users could not be permitted to take part in construction work owing to their lack of knowledge about safety aspects, costs, maintenance and the like. This became a dilemma for the managers, since the users did not always find them accommodating.

\section{Effects of user participation in municipality $\mathbf{Y}$}

The playground provision in municipality Y appeared to have been developed according to strategies set by politicians, in combination with ideas of the managers. Some diversification was found, with different sized playgrounds and with some units being combined with football fields or with surrounding nature or shrubbery. Actual playground provision was 
somewhat more uniform than in municipality $\mathrm{X}$, and there were no playgrounds in the most central parts, although the two very large units were situated just outside the centre. However playground provision in the regional centre of both municipalities included some very large playgrounds, combined playgrounds with space for other outdoor activities (e.g. football fields) and retained green elements close to play settings. In municipality $\mathrm{Y}$, just as in $\mathrm{X}$, most playgrounds were still rather traditional, physically limited spaces with prefabricated play equipment, but playground managers had also considered alternative approaches such as developing multi-functional meeting places.

The managers had in several cases considered the preferences expressed by users and had let such preferences affect the playgrounds, mainly by adding specific play equipment if there was enough space for it. They had also noticed effects of their strategy among users, with e.g. the large playground for younger children becoming much visited and having developed into a popular destination for outings by families, preschools, etc. The two managers interviewed had also learned more about user needs and preferences from their contacts with users, but had not developed a common view on what was needed or on how to improve provision further. Being able to satisfy user preferences was considered positive, but problems preventing these preferences from being fulfilled because of limitations caused by space, money or safety standards connected to users' lack of knowledge of these appeared to have some negative effects on the attitudes of the managers towards user involvement.

Strategic thoughts and patterns of action about how to make the playground provision provide as much benefits for the users as possible had been developed during years of work. Both interviewees mentioned working towards personal ideals, although lacking shared goals within the management organisation. Large-scale user participation was not considered 
suitable, since the politicians made the decisions, but adapting to user needs and preferences in informal ways was favoured. In municipality $\mathrm{Y}$ too, developing a digital register of the playgrounds to get an overview was a task on the agenda, as was work on meeting standards on equipment safety and legislation on disabled access.

\section{Discussion}

This paper describes two of many possible ways to implement strategies for user participation concerning municipal playgrounds and their effects on managers and playgrounds. The different approaches affected the managers' attitudes and the status of their work. The physical playgrounds were also affected by the different approaches, although the two municipalities had developed some similarities in playground provision. Playground management in the two municipalities differed in terms of the professionals involved, how and where decisions were made and how the tactical and operational levels were organised internally and in relation to politicians and users. Some differences and similarities found and potential lessons to be learned from the results are discussed below.

Similarly to Guest and Taylor (1999) and Randrup and Persson (2009), this study shows the importance of the tactical activity level in implementing strategies, taking initiatives, involving users and developing ideas. Lack of activity on the tactical level appeared to cause problems in implementing strategies (municipality Y). Involving large numbers of persons on the tactical level, including professionals from different disciplines, and taking the initiative for strategies to be set by politicians and users to be involved were associated with a shared positive view within the organisation and good communication between levels and groups (as proposed by Grint, 1994) but had not guaranteed that long-term strategies were set (municipality X). 
Having several individuals with different positions within an organisation share the responsibility for playground development also might play a role in giving the 'minor' issue of playground provision higher status within the municipal organisation and lead to the development of knowledge among many individuals (municipality X). It might even increase the will to try out new methods and approaches, compared with organisations where playground management is an issue for park managers only and is more marginalised, like in municipality Y. The cooperation approach recommended by Randrup and Persson (2009) appeared to have made the professionals in municipality X work increasingly towards shared goals, as recommended by Rodrigues and Halvorson (1996).

Experiences from user participation processes (municipality X), in comparison with informal user consultation (municipality Y), appeared to be particularly positive for the professionals involved, giving them increased knowledge about users and positive attitudes towards them, their abilities and their potential for participation. Active dialogue with users and politicians during the process also allowed for changes and rationalisations in playground provision, creating the conditions for more efficient management without negative reactions, something which was feared in municipality Y.

Participation processes, although positive for the managers, also risk problematic consequences such as some public playgrounds acquiring a rather private character, with active users preferring to prioritise their own closest playground (municipality X). This is questionable in view of the fact that playgrounds are intended to be public facilities and that the active users tend to change rapidly. There also appears to be a risk of losing the positive effects from user participation if the process is not kept going but becomes a one-off event. 
The fact that most interviewees in municipality $\mathrm{X}$ are no longer involved with the participation process shows that this mainly successful process risks ending up in a lack of continuity in terms of user contact.

Management work may involve much decision-making, which to some extent can be tactical and allow continuous adaptation to user needs on the small-scale level of individual playgrounds (municipality Y). This approach to user participation appeared to result in some positive experiences for the managers on a personal level and also has the potential to become continuous. However, the approach had some associated problems, such as finding users’ knowledge about the conditions for playground management insufficient and the difficulties in making rationalisations as regards playground provision.

Despite large differences in organisational structure, strategy and attitudes in the two cases, the actual playground provision was in many ways rather similar, with mainly traditional, small playgrounds and a few large units, combined functions and green elements included in the settings. There are several possible reasons for these similarities. The establishment of some very large playgrounds can be considered to follow a general trend in Sweden (Jansson, 2008). Both users and managers may also have deeply embedded conceptions of what a playground should comprise, which may be little changed except through direct inspiration. However, the similarities might also show that the different two approaches to user participation can actually give similar effects in the physical playgrounds. If that is the case, the informal user involvement in municipality Y may have achieved those effects with less effort than in municipality X. 
As found by Beierle and Koninsky (2001), participation processes might be more successful in increasing knowledge and understanding among those involved than in practical implementation. Focusing on allocated playground units, equipment, safety standards and budget might be positive for the dialogue between managers and users, but it is questionable whether this is an appropriate starting point for children's participation, which according to Kylin (2004) needs to begin with professionals understanding children’s perspectives, not vice versa. The benefits arising from the participatory process in municipality $\mathrm{X}$ in comparison with municipality Y can be described as mainly applying to the managers, although some effects were found in the playgrounds. There may be reason to criticise how the participation process in municipality $\mathrm{X}$ was conducted, which can have resulted in the outcome being rather traditional.

\section{Conclusions}

Qualitative studies about municipal management of play facilities are rare, and more studies are needed to determine how the work can be organised to give playground provision that corresponds to the needs and preferences of users. There is particular reason to further research and discuss the types of professionals that should be involved in playground management, the tasks they should focus on, and the ways in which users should participate in the process.

This study shows the importance of organisational and strategic questions in the management of public playgrounds. The results highlight the need for further development of the tactical level of playground management and for cooperation within the organisation to enable work on more strategic levels, facilitate user participation and other non-traditional approaches and increase the status of playground management. 
Some main conclusions and practical implications from the study are:

- User participation can produce important knowledge and positive experiences for the managers.

- Continuity in the management approach and user participation and more child-centred user participation approaches appears to be important in adapting to user needs.

- Cooperation within the municipal organisation can result in positive effects on management organisations and their focus.

- The effects of different strategic approaches to user participation on physical playgrounds are less apparent than effects on managers' attitudes, an area that needs to be given more attention in future research.

\section{Acknowledgements}

The research studies reported in this paper were possible thanks to the engagement and cooperation of playground managers in the two anonymous municipalities. The authors also wish to thank two anonymous referees for useful comments on an earlier version of this paper.

\section{References}

Albrechts, L. Healey, P. and Kunzmann, K. (2003) Strategic spatial planning and regional governance in Europe. Journal of the American Planning Association, 69, 113-129.

Beierle, T.C. and Konisky, D.M. (2001) What are we gaining from stakeholder involvement? Observations from environmental planning in the Great Lakes. Environment and Planning C: Government and Policy, 19, 515-527. 
Bergström, T. Magnusson, H. and Ramberg, U. (2008) Through a Glass Darkly: Leadership Complexity in Swedish Local Government. Local Government Studies, 34(2), 203-220. Björklid, P. and Nordström, M. (2007) Environmental child-friendliness: collaboration and future research. Children, Youth and Environments, 17(4), 388-401.

Bryman, A. (2008) Social Research Methods, London, Oxford University Press.

Bryson, J.M. (1995) Strategic planning for public and nonprofit organisations, San Francisco, Jossey-Bass.

Bucht, E. (1997) Public Parks in Sweden 1860-1960: The Planning and Design Discourse, Alnarp, Swedish University of Agricultural Sciences.

Cele, S. (2006) Communicating Place: Methods for understanding children's experience of place, Stockholm, Stockholm University.

Dereli, C. (2003) Strategy and strategic decision-making in the smaller local authority. The International Journal of Public Sector Management, 16(4), 250-260.

Eriksen, A. (1985) Playground design: Outdoor Environments for Learning and Development New York, Van Nostrand Reinhold Company.

Fernandez, S. and Rainey, H.G. (2006) Managing Successful Organizational Change in the Public Sector. Public Administration Review, 66 (2), 168-176.

Francis, M. and Lorenzo, R. (2002) Seven realms of children's participation. Journal of Environmental Psychology, 22, 157-169.

Freeman, C. and Aitken-Rose, E. (2005) Future shapers: children, young people, and planning in New Zealand local government. Environment and Planning C: Government and Policy, 23(2), 227-246.

Frost, J. (1986) Children’s playgrounds: Research and practice, in: G. Fein, and M. Rivkin (eds) The Young Child at Play: Reviews of Research, Washington DC, National Association for Publication, pp. 195-212. 
Frye, M.V. (1964) The Historical Development of Municipal Parks in the United States: Concepts and their Application, Michigan, Ann Arbor.

Ghemawat, P. (2006) Strategy and the Business Landscape (2nd ed.), New Jersey, Prentice Hall.

Goodlad, R. Burton, P. and Croft, J. (2005) Effectiveness at what? The process and impact of community involvement in area-based initiatives. Environment and Planning C: Government and Policy, 23(6), 923-938.

Grint, K. (1994) Reengineering history: social resonances and business process reengineering Organisation, 1(1), 179-201.

Guest, C. and Taylor, P. (1999) Customer oriented public leisure services in the United Kingdom. Managing Leisure, 4, 94-106.

Hart, R. (1992) Children's Participation: From Tokenism to Citizenship, Florence, Unicef.

Hart, R. (2002) Containing children: some lessons on planning for play from New York City. Environment \& Urbanization, 14(2), 135-148.

Iltus, S. and Hart, R. (1995) Participatory planning and design of recreational spaces with children. Architecture \& Behavior, 10(10), 339-370.

Jansson, M. (2008) Kommunala lekplatser i tider av förändring [Municipal playgrounds in times of change], see: http://pub-epsilon.slu.se/471/01/marit_jansson_090108.pdf.

Jansson, M. and Persson, B. (2010). Playground planning and management: An evaluation of standard-influenced provision through user needs. Urban Forestry and Urban Greening, 9(1), 33-42.

Joyce, P. (2000) Strategy in the Public Sector: A Guide to Effective Change Management, Chichester, John Wiley. 
Knutsson, H. Mattisson, O. Ramberg, U. and Tagesson, T. (2008) Do strategy and management matter in municipal organisations? Financial Accountability \& Management, 24 (3), 297-321.

Kylin, M. (2004) Från koja till plan [From Den to Plan], Alnarp, Swedish University of Agricultural Sciences.

Maddock, S. (2002) Making modernisation work: New narratives, change, strategies and people management in the public sector. The International Journal of Public Sector Management, 15(1), 13-43.

Mattisson, O. (2000) Kommunala huvudmannastrategier för kostnadspress och utveckling en studie av kommunal teknik [Municipal responsible authorities’ strategies for cost reduction and innovation - a study of the municipal engineering sector], Lund, Lund

Mintzberg, H. Ahlstrand, B. and Lampel, J. (1998) Strategy Safari: A guided tour through the wilds of strategic management, New York, The Free Press.

Nairn, K. Sligo, J. and Freeman, C. (2006) Polarizing Participation in Local Government: Which young people are included and excluded? Children, Youth and Environments, 16(2), 248-271.

Naylor, H. (1985) Outdoor play and play equipment. Early Child Development and Care, 19(1), 109-130.

Pandey, S. K. and Garnett, J. L. (2006) Exploring public sector communication performance: Testing a model and drawing implications. Public Administration Review, 66(1), 37-51.

Poister, T.H. and Streib, G. (1999) Strategic management in the public sector: concepts, models and processes. Public Management and Productivity Review, 22, 308-325.

Power, M. (1997) The Audit Society -Rituals of Verifications. Oxford, Oxford University Press. 
Prellwitz, M. and Tamm, M. (1999) Attitudes of key persons to accessibility problems in playgrounds for children with restricted mobility: a study in a medium-sized municipality in northern Sweden. Scandinavian Journal of Occupational Therapy, 6, 166-173.

Quigg, R. (1999) Field Notes: Re-Designing Playgrounds - Strategic Provision of Playscapes in Dunedin, New Zealand. Built environment, 25(1), 58-60.

Quinn, J. B. (1982) Managing strategies incrementally. Omega, 10(6), 613-627.

Randrup, T. B. and Persson, B. (2009) Public green spaces in the Nordic countries: development of a new strategic management regime. Urban Forestry and Urban Greening, 8(1), 31-40.

Rodrigues, M. and Halvorson, J. (1996) People: hearts and minds. The city of Mississauga, Canada. Public Administration and Development, 16, 295-304.

Rumelt, R. Schendel, D. and Teece, D. (1994) Fundamental Issues in Strategy, Harvard Business School Press.

Stake, R. E. (1995) The Art of Case Study Research, California, Sage Publications.

Taylor, P. Godfrey, A. Back, P. Bennett, L. Sinclair, P. and Kapasi, H. (2008) Testing the feasibility of performance indicators for play facilities in England. Managing Leisure, 13, 207-226.

Tonucci, F. and Rissotto, A. (2001) Why do we need children's participation? The importance of children's participation in changing the city. Journal of Community \& Applied Social Psychology, 11, 407-419.

Tourish, D. and Tourish, B. (1996) Assessing staff-management relationships in local authority leisure facilities: the communication audit approach. Managing Leisure, 1, 91104.

Vedung, E. (2006) Evaluation Research, in: B. G. Peters and J. Pierre (eds) Handbook of Public Policy, London, Sage, pp. 397-416. 
Walker, R. M. and Boyne, G. A. (2006) Public management reform and organisational performance: an empirical assessment of the U.K. Labour government's public service improvement strategy. Journal of Policy Analysis and Management, 25(2), 371-393.

Wichowsky, A., and Moynihan, D. P., (2008). Measuring How Administration Shapes Citizenship: A Policy Feedback Perspective on Performance Management. Public Administration Review. September-October.

Woolley, H. (2007) Where do the children play? How policies can influence practice, Municipal Engineer, 160, 89-95. 
